\title{
Oral corrective feedback in language teaching: A historical perspective
}

DOI: https://doi.org/10.21897/25394185.1482

\section{Respuesta correctiva oral en la enseñanza del Inglés: Una perspectiva histórica}

\section{Rod Ellis, r.ellis@auckland.ac.nz}

Curtin University, Perth, Australia.

Shanghai International Studies University, Shanghai, China.

\section{Abstract}

This paper reviews the role of corrective feedback in language teaching and learning in the last fifty years. It reports research studies on error correction from the view of different learning theories and language methods. This extensive and varied revision is used to revisit Hendrickson's (1978) five key questions on error correction, thus guiding language teachers to inform their decisions on the treatment of learners' errors. Finally, it suggests unexplored aspects of error correction like corrective feedback in small group work and in computer-mediated communication.

Keywords: SLA, corrective feedback.

\section{Resumen}

Este articulo revisa el rol del la respuesta correctiva dentro de la enseñanza y aprendizaje de idiomas en los últimos cincuenta años. Se reportan estudios sobre la respuesta correctiva desde el punto de vista de diferentes teorias del aprendizaje y metodos de enseñanza. Esta revision extensa y variada sirve para discutir nuevamente las cinco preguntas de Hendrickson (1978) sobre la correccion de errores; de esta manera, guiando a los profesores de idiomas a informar sus decisiones sobre el tratamiento de los errores de los estudiantes. Finalmente, se sugieren aspectos aun no explorados en la correccion de errores como la respuesta correctiva durante los trabajos grupales pequeños y en la comunicación mediada por computadores.

Palabras claves: SLA, corrective feedback. 


\section{Introduction}

In 1978, Hendrickson published a seminal article on 'error correction'. He began his article by pointing out the change in attitudes to errors that occurred in the late 1960s. Prior to that, in accordance with the theory of language that gave rise to the audiolingual method, errors were seen as not only unwanted but as damaging to learning and thus emphasis was placed on avoiding them by carefully controlling second language (L2) learners' production. From the late 1960s, however, errors began to be seen as natural and inevitable when learners were using the L2 to communicate. Error correction now became a topic of interest. Hendrickson noted that there was uncertainty in how to deal with errors and limited research to draw on. He then undertook a systematic review of the existing literature by addressing five key questions. I have summarized the conclusions he came to in Table 1.

Table 1: Summary of Hendrickson (1978)

\begin{tabular}{ll}
\hline \multicolumn{1}{c}{ Question1 } & \multicolumn{1}{c}{ Hendrickson's conclusions } \\
\hline Should learner errors be corrected? & $\begin{array}{l}\text { Errors should be corrected as it helps learners discover } \\
\text { the functions and limitations of linguistic forms. It is } \\
\text { especially helpful for adult L2 learners. } \\
\text { Some errors should be tolerated when learners are } \\
\text { communicating; correction is more clearly needed in } \\
\text { manipulative grammar practice. }\end{array}$ \\
Which learner errors should be corrected? & $\begin{array}{l}\text { A strong case can be made for correcting errors that } \\
\text { (1) interfere with the meaning of a message should be }\end{array}$ \\
corrected (e.g. global versus local errors (Burt, 1975), \\
(2) may stigmatize learners from the perspective \\
of native speakers, and (3) are high frequency and \\
ignoring other types of errors. \\
Hendrickson considered a number of views about \\
how to correct (e.g. direct vs. indirect; systematic; \\
tailored to the individual learner). He was unable to \\
reach a clear answer to this question but he queried the \\
usefulness of direct correction (i.e. giving the learner \\
the correct form). \\
The teacher has a clear role in correcting learner errors \\
but peer-correction or self-correction is favoured. \\
Hendrickson concluded that who should correct may \\
depend on which errors are corrected, when and how.
\end{tabular}

Hendrickson drew on a number of empirical studies of error correction (especially regarding question 4) but the clear message that comes from his article is «the literature on the correction of second language errors is quite speculative and relatively scant» (p. 396). He concluded by emphasizing the need for research to test the different proposals.

\section{Early research}

The earliest studies of corrective feedback were descriptive in nature. Actual lessons were audiorecorded, transcribed, and the various ways in which teachers conducted correction identified and classified.

One of the conclusions of the early studies was that correcting learners' errors is a very complex 
process. This is evident in the elaborateness of the discourse and category systems that were developed to account for the correction processes. Chaudron's (1977) Descriptive Model of Discourse in the Corrective Treatment of Learner Error distinguished «types» and «features» which constituted the «elemental 'acts' of corrective discourse». He defined «features» as the linguistic or discursive markers such as stress or attention-getters that are bound to larger utterances and «types» as self-standing, unbound utterances (i.e. repeating a student utterance with rising intonation). He distinguished a total of 31 features, types and combinations of both. He also drew up a highly complex flow-chart model of corrective discourse showing the various options available to teachers and how one option led into another. For example, if an error occurred the teacher could choose to ignore it or address it and if the latter either delay correction or interrupt the learner. These choices led to further possibilities, some optional and some mandatory. Chaudron's model is probably the most complete and complex description of corrective feedback ever produced. Similar descriptive studies by Allwright (1975), Fanselow (1977) and Long(1977) also pointed to its complexity.

The research showed that some errors are more likely to be treated than others (e.g. lexical errors receive more attention than grammatical errors. The research also showed that there is considerable variation among teachers regarding the frequency with which errors are corrected and the preferred manner in which they are corrected. Teachers often simultaneously provide more than one type of feedback on the same error. However, they do not correct all errors and are less likely to correct an error if it occurs frequently. Also on occasions teachers were observed to correct 'errors' that did not in fact exist (Edmundson 1985).

Two general characteristics of teachers' error correction practices emerged from these early descriptive studies - imprecision and inconsistency. Imprecision is evident in the fact that teachers use the same overt behaviour (e.g. 'repetition') to both indicate that an error has been made and to reinforce a correct response. Nystrom (1983) commented: 'Teachers typically are unable to sort through the feedback options available to them and arrive at an appropriate response'. Inconsistency arises when teachers respond variably to the same error made by different students in the same class, correcting some students and ignoring others. For Long (1977) this was undesirable as it was likely to confuse learners. However, as Allwright (1975) pointed out such inconsistency may just reflect teachers' attempts to cater for individual differences among the students.

The value of these early descriptive studies is that they showed us what teachers actually do as opposed to what teachers think they do or teacher educators think teachers should do. The very fact that oral corrective feedback was shown to be complex should be a warning against simplistic recipes for correction. Oral correction takes place online and thus inevitably teachers will need to respond to the exigencies of the moment taking into account numerous factors relating to the instructional context, the particular student who made the error, and the ongoing discourse. Only if correction is delayed until after an activity has been completed (a possibility considered later) are teachers likely and able to make deliberate decisions about whether and how to correct and who should do it.

\section{Some Later descriptive studies}

Descriptive studies continued to flourish. By far the most influential is Lyster and Ranta's (1997) study of corrective feedback in French immersion classrooms. This study addressed three research questions: (1) What were the different types of corrective feedback used by the teachers? (2) What kinds of student uptake of the correction occurred? (3) What was the relationship between the different types of feedback and uptake involving student repair of their errors? Uptake was defined as the student response to the feedback move. Lyster and Ranta were interested in whether learners ended up 
correcting their errors themselves following the different feedback strategies. Potentially, then, this study could provide a basis for recommending which type of feedback teachers should employ (i.e. those strategies most likely to result in learners repairing their errors).

Lyster and Ranta identified six basic corrective strategies. Given the influence that this taxonomy has had on corrective feedback research, I have provided definitions of the six strategies along with examples (taken from Lyster and Ranta's article) in Table 2.An important point about this taxonomy is that it can be applied to both correction that is didactic (i.e. directed purely at linguistic correctness) and communicative (i.e. directed at resolving communication problems). Subsequent studies (e.g. Sheen, 2004) have shown that the same strategies are found in other types of language classrooms.

Table 2: Taxonomy of teachers' corrective strategies (Lyster and Ranta, 1997; 46-49)

\begin{tabular}{|c|c|c|}
\hline Corrective strategy & Definition & Example \\
\hline Explicit correction & $\begin{array}{l}\text { 'the explicit provision of the correct } \\
\text { form .... the teacher clearly indicates } \\
\text { that what the student said was incorrect' }\end{array}$ & $\begin{array}{l}\text { S: La note pour le shot. } \\
\mathrm{T}: \text { Oh, pur la, oh, pur ca. Tu veux dire } \\
\text { pour la piqure. Piqure. Oui? }\end{array}$ \\
\hline Recasts & $\begin{array}{l}\text { 'reformulation of all or part of student's } \\
\text { utterance, minus the error' }\end{array}$ & $\begin{array}{l}\text { S: L'eau erable? } \\
\text { T: L'eau d'erable. }\end{array}$ \\
\hline Clarification requests & $\begin{array}{l}\text { 'indicate to students either that their } \\
\text { utterance has been misunderstood by } \\
\text { the teacher or that the utterance is ill- } \\
\text { formed in some way' }\end{array}$ & $\begin{array}{l}\text { S: Est-ce que, est-ce que je peux fait } \\
\text { une carte sur le ... pur mon petit frere } \\
\text { sur le computer? } \\
\mathrm{T}: \text { Pardon? }\end{array}$ \\
\hline Metalinguistic feedback & $\begin{array}{l}\text { 'contains comments, information, } \\
\text { or questions related to the well- } \\
\text { formedness of the student's utterance, } \\
\text { without explicitly providing the correct } \\
\text { form' }\end{array}$ & $\begin{array}{l}\text { S: Euhm, le, le elephant. Le elephant } \\
\text { gronde. } \\
\text { T: est-ce qu'on dit le elephant? }\end{array}$ \\
\hline Elicitation & $\begin{array}{l}\text { This is of three kinds: the teacher } \\
\text { (1) elicits completion of his/her own } \\
\text { utterance, (2) uses a question to elicit } \\
\text { the correct form, (3) asks a student to } \\
\text { reformulate his/her utterance. }\end{array}$ & $\begin{array}{l}\mathrm{S}: \text { Le chien peut court. } \\
\mathrm{T}: \text { le chien peut court ? Le chien peut } \\
\ldots\end{array}$ \\
\hline Repetition & $\begin{array}{l}\text { 'the teacher's repetition, in isolation, of } \\
\text { the student's erroneous utterance' }\end{array}$ & $\begin{array}{l}\text { S: Le .... Le girafe? } \\
\text { T: Le girafe? }\end{array}$ \\
\hline
\end{tabular}

By far the most frequent of the six types was recasts, which accounted for $55 \%$ of the total corrective moves. However, recasts were the least likely to result in uptake with repair (i.e. learners typically did not follow up a recast by correcting their errors). Output-prompting types of feedback (e.g. clarification requests and elicitation) were much more likely to result in students repairing their errors.

The results of this study led Lyster (1998) to propose that output-prompting feedback was more 
likely to promote learning than recasts on the grounds that it pushed learners to self-correct. However, he argued that teacher repetition was unlikely to be effective because it was ambiguous; teachers sometimes repeated a student utterance that was correct, making it difficult for learners to know whether repetition signalled they had made an error. Lyster argued that recasts were a less effective way of performing correction because they were less likely to result in learners repairing their errors. However, these were extrapolations from the descriptive study, which did not in itself show which type of corrective feedback was most beneficial for acquisition. They were premised on the theoretical claim that production of the correct form facilitates acquisition. An alternative theoretical perspective (see Long, 1996), however, views acquisition as primarily input-driven and emphasizes the importance of providing learners with the correct form as recasts do.

Aljaafreh and Lantolf(1994) reported a descriptive study based on whether the strategy is implicit (i.e. the corrective force is hidden) or explicit (i.e. the corrective force is explicit). They examined writing conferences where a tutor provided oral feedback on students' written work. They developed a 'regulatory scale' to reflect the extent to which the oral feedback provided by the writing tutor was implicit or explicit. For example, asking learners to find and correct their own errors constitutes an implicit strategy while providing examples of the correct pattern is a highly explicit strategy. An intermediate level occurs when the tutor indicates the nature of an error without identifying it for the learner. The complete scale is shown in Table 3. This scale was informed by sociocultural theory according to which corrective feedback is effective if it is fine-tuned to the learner's development (i.e. provides the minimal assistance needed to induce a self-correction). Aljaafreh and Lantolf argued that for corrective feedback to be effective for learning it needed to be 'graduated'.

Table 3: Regulatory scale-implicit to explicit (Aljaafreh and Lantolf 1994: 471)

\footnotetext{
0 Tutor asks the learner to read, find the errors, and correct them independently, prior to the tutorial.

1 Construction of a 'collaborative frame' prompted by the presence of the tutor as a potential dialogic partner.

2 Prompted or focused reading of the sentence that contains the error by the learner or the tutor.

3 Tutor indicates that something may be wrong in a segment (for example, sentence, clause, line) 'Is there anything wrong in this sentence?'

4 Tutor rejects unsuccessful attempts at recognizing the error.

5 Tutor narrows down the location of the error (for example, tutor repeats or points to the specific segment which contains the error).

6 Tutor indicates the nature of the error, but does not identify the error (for example, 'There is something wrong with the tense marking here').

7 Tutor identifies the error ('You can't use an auxiliary here').

8 Tutor rejects learner's unsuccessful attempts at correcting error.

9 Tutor provides clues to help the learner arrive at the correct form (for example, 'It is not really past but something that is still going on').

10 Tutor provides the correct form.

11 Tutor provides some explanation for use of the correct form.

12 Tutor provides examples of the correct pattern when other forms of help fail to produce an appropriate responsive action.
} 
Unlike the earlier descriptive studies, the later ones were not purely descriptive; they were informed by theories drawn from second language acquisition research - skill-learning theory in the case of Lyster and Ranta and sociocultural theory in the case of Aljaafreh and Lantolf. In this way the researchers were able to move beyond simply showing how teachers do correction to proposing what types of corrective feedback facilitate L2 acquisition. However, descriptive studies do not provide evidence that correction assists acquisition if this is defined as involving change in long-term memory. Nor can they show which type is most effective. Ideally, experimental studies are needed to reveal a cause-and-effect relationship between corrective feedback and acquisition [1].

\section{Experimental studies}

What might be called the 'experimental phase' in corrective feedback research began in earnest in the 1990s and has continued up to today. Studies have addressed four principal questions:

Does corrective feedback in the context of performing a communicative task assist acquisition of specific target language features?

Do some corrective procedures have a greater effect on acquisition than other procedures?

Does 'noticing 'mediate the effect that corrective feedback has on the acquisition of specific target language features?

Which individual learner factors mediate the effect that corrective feedback has on acquisition?

Some studies were carried out under laboratory conditions while others were conducted in classrooms. I will not attempt a survey of all the studies but instead consider a number of seminal studies that have addressed each of the four research questions.

a. The effect of corrective feedback on L2 acquisition: The answer to this question might seem fairly obvious to teachers. But in fact, the value of corrective feedback is disputed. Krashen (1982) for example, suggested that it plays no role in 'acquisition' but can assist 'learning'. As true competence in a language rests on 'acquisition', it follows that from this perspective corrective feedback is of little value.

Research, however, has demonstrated otherwise. Spada and Lightbown's (1993) classroom-based study investigated the effects of form-focused instruction and corrective feedback on the L2 acquisition of question formation in an intensive communicative ESL program for francophone learners of English in Quebec, Canada. Two experimental classes received 5 hours of explicit instruction on English question formation with follow-up practice activities where teachers were encouraged to give corrective feedback. A comparison group simply carried on with its normal instructional programme (i. e. did not receive the explicit instruction). Acquisition of interrogatives was measured by asking learners to perform an oral communicative task. The results were surprising. Spada and Lightbown reported that the comparison group outperformed the experimental groups. To try to explain this finding they examined the actual interactions that took place in all the classrooms and found that the teacher in the comparison group classroom asked many more questions than the teachers in the experimental classrooms and also corrected her students' errors much more frequently. Spada and Lightbown concluded that the success of the comparison group students in acquiring question forms derived from the corrective feedback that these students received while they were performing communicative activities. This study provides an answer to the first research question. It also points to the importance of examining what actually happens when instruction takes place in an experimental study. 
b. The effects of different types of corrective feedback: Several studies have addressed research question (2). These have focused on two key dimensions of corrective feedback - input-providing vs. output-put prompting and implicit vs. explicit. Table 4 below shows how the specific corrective strategies can be classified in terms of these two dimensions.

Table 4: A classification of CF strategies (based on Sheen and Ellis, 2011)

\begin{tabular}{lll}
\hline & Implicit & Explicit \\
\hline Input-providing & 1. Conversational recasts & $\begin{array}{l}\text { Didactic recasts } \\
\text { Explicit corrections }\end{array}$ \\
& & \\
Output-prompting & Repetitions & Metalinguistic comments \\
& Clarification requests & Elicitations \\
& & Paralinguistic signals [2] \\
\hline
\end{tabular}

Lyster (2004) investigated 148 (grade 5) 10-11 year olds in a French immersion programme focusing on grammatical gender (i.e. choice of article with nouns). One experimental group received recasts and another prompts. There was also a control group that received no feedback. All three groups also received form-focused instruction in the target feature. The results favoured the group receiving prompts although recasts were also shown to facilitate acquisition. Several later studies also pointed to the superior effect of output-prompting feedback. However, it is possible that the advantage found for prompts such as elicitation was due to the fact that they were more explicit than the recasts rather than because they pushed learners to self-correct. Mifka-Profozic (2013) carried out a study that compared the effects of an implicit input-providing strategy (i.e. recasts) and an implicit prompt (requests for clarification) on the acquisition of two French verb forms (passé compose and imparfait) by 50 high school students in New Zealand. She found that the learners who received recasts progressed more than those who received the prompt. The instructional context may also play a role. Prompts may be more effective than recasts when the general tenor of the classroom is communicative but recasts may work better in a form-focused instructional context where learners are more likely to pay attention to recasts even though they are implicit [3] because they are oriented to look out for their errors.

Several studies have compared implicit and explicit types of corrective feedback. A good example is Ellis, Loewen and Erlam (2006). They investigated the effects of recasts (as an implicit type) and metalinguistic comments (as an explicit type) on the acquisition of English regular past tense by 34 low-intermediate adult ESL students in New Zealand. The CF groups performed two 30 minute communicative tasks and received feedback on their past tense -ed errors. A key feature of this study is that it attempted to measure acquisition in terms of the learners' implicit knowledge (measured by means of an oral imitation test) and explicit knowledge (measured by means of an untimed grammaticality judgement test and a metalinguistic knowledge test. This is important to address the Krashen's (1982) claim that corrective feedback only benefits 'learning' (i.e. explicit knowledge). Ellis et al. first established that frequency of the feedback provided to the learners in the two experimental groups was roughly equivalent. The results showed that the group receiving repetition of an incorrect verb form followed by a metalinguistic comment outperformed both the control group and the recasts 
group in both the oral imitation test and the untimed grammaticality judgement test although the differences only reached statistical significance in the delayed post-tests. This study then points to the superiority of explicit feedback and suggests that it impacts on both learners' explicit and implicit knowledge.

These studies were informed by theories of L2 acquisition. The case for correcting by means of prompts receives support from skill-learning theory while the case for recasts rests on theories that emphasize the role of input in language learning (e.g. Krashen, 1985). According to sociocultural theory, however, it is not the type of corrective feedback that is crucial but tailoring the feedback to the learner's level of development. That is, this theory claims that no more help than is necessary to enable a learner to self-correct should be provided and therefore that for some learners explicit feedback will be needed but for other learners implicit feedback will do the job. A study by Nassaji and Swain (2000) lends some support to this claim. They investigated two Korean learners of English. One learner was provided with graduated assistance (i.e. the tutor systematically worked through the scale in Table 3 scale to negotiate the feedback supplied) while the other learner was given only random help (i.e. the tutor was supplied with a random list of correcting strategies drawn from Aljaafreh and Lantolf's regulatory scale). Nassaji and Swain reported that systematic graduated feedback was more effective in assisting development. However, a limitation of this study is that' ${ }^{\text {'random feedback' }}$ is highly unnatural very unlikely to occur in actual teaching. To address this problem, Erlam, Ellis and Batstone (2015) compared the effects of graduated feedback and explicit correction on two grammatical structures - English past tense and articles. They found that graduated feedback was more effective than explicit correction for articles but that explicit feedback was just as effective as graduated feedback for past tense.

These studies have produced conflicting results and it is clearly not possible to point to a particular type of corrective feedback that is invariably the most effective. This is not surprising. As we noted when considering the early descriptive studies, corrective feedback is a complex phenomenon and thus it is unlikely that a clear answer to research question (2) will be forthcoming. Nevertheless, it would seem that although explicit types of feedback are not always needed, in general they are the more effective. What is arguably crucial for feedback to impact on acquisition is that it is salient to learners and is attended to. This is more likely to happen if the feedback is explicit. This suggests that teachers need to guard against the overuse of recasts, which are generally implicit.

c. Noticing as a mediating factor on the effect of corrective feedback: On the grounds that corrective feedback can only have an effect on learners' developing L2 systems if it is attended to, researchers, have investigated whether the corrections that learners receive are noticed and whether 'noticing' promotes learning. 'Noticing' is a technical term (Schmidt, 1990) that refers to the conscious attention that learners pay to linguistic forms they are exposed to in the input. Far fewer studies have sought an answer to this question. There is clear evidence that learners do notice the corrections they receive even in implicit types of corrective feedback such as recasts (Egi, 2007) but there is little evidence to show a consistent direct effect of such noticing on acquisition. Mackey (2006), for example, reported that learners who received corrective feedback while performing a communicative task reported a much higher level of noticing of three target structures than other learners who performed the task without corrective feedback but that the level of noticing varied considerably according to structure (e.g. more for question forms than for past tense or plurals) and that a relationship between noticing and acquisition was only evident for the frequently-noticed structure. 
Both Egi and Mackey obtained evidence about noticing by eliciting self-reports from learners after they had completed the communicative tasks during which they received feedback. An alternative way of obtaining evidence of noticing is to examine whether learners successfully self-correct an error following feedback (i.e. whether 'uptake with repair' occurs). If learners do self-correct, then, they must have noticed the correction. The importance of self-correcting errors for acquisition, however, is a matter of controversy. Some researchers (e.g. Long, 2006) argued that recasts assist learning by inducing learners to notice the correction and that whether they subsequently repair their errors is immaterial. Other researchers (e.g. Lyster, 2004) draw on skill-learning theory to argue that uptake of the correction is important for acquisition. This is an important issue but it has been little investigated. Ellis and Mifka-Profozic (2013) found no evidence that repairing errors following recasts and clarification requests was related to acquisition and concluded that it is noticing rather than repair that is important for acquisition. However, Loewen (2005), in a non-experimental study, examined the relationship between corrective feedback episodes where uptake occurred in adult ESL lessons and the learners' acquisition of those forms that had been corrected. He administered tailormade tests shortly after the lessons or two weeks later to measure acquisition. He reported that those learners who had corrected their errors during the lesson were more likely to demonstrate knowledge of the correct forms in the tests. Perhaps, then, learners can benefit from corrective feedback even if they do not repair their errors but when they do deeper processing may occur which assists learning.

d. Individual learner factors and the effect of corrective feedback: The fourth question concerns the role that individual learner factors play in the effect that corrective feedback has on acquisition. Interest in this issue has increased over time as researchers came to recognize the importance of taking factors such as language aptitude, language anxiety and working memory into account when investigating the effects of corrective feedback. Two studies illustrate the kind of research that has addressed this issue.

Sheen (2008) investigated whether language anxiety, measured by means of a questionnaire, affected ESL learners'noticing that their teacher had recast their erroneous utterances (as shown by whether the learners repaired their errors) and also whether it had an effect on subsequent learning. She found that the low anxiety learners were much more likely to repair their errors following recasts and consequently learn from them. This study, then, suggests that high anxiety can impede learning because it interferes with the learners' ability to process input in their working memory.

Révész (2012) investigated the role of learners' phonological short-term memory (i.e. the capacity to hold aural information in memory) and their complex working memory (i.e. the capacity to process information held in short-term memory) in the learning that took place as a result of performing communicative tasks. One group just performed the tasks while the other received recasts. Révész found no relationship between working memory and gains in the target structure in those learners who just performed the task. In contrast, there was a relationship for those learners who received recasts. Phonological working memory was related to accuracy gains in an oral description task while measures of complex working memory were related to gains in written tests. Révész suggested that those learners with high phonological short-term memory benefited from the recasts because they were able to maintain the information in short-term memory longer, which contributed to the development of the procedural knowledge needed for oral production while those learners with stronger complex working memory were able to consciously attend to and analyse the information provided by the recasts, which led to the declarative knowledge helpful for written production.

Exploring how individual learner factors affect learners' ability to benefit from corrective feedback 
has become one of the major goals of current research. Interest has focused on learners' cognitive abilities - working memory and language aptitude - but as Sheen's study indicated, affective factors such as language anxiety are likely to influence the extent to which learners engage with the feedback they receive.

e. A final issue: All of the experimental studies referred to above investigated the effects of corrective feedback when learners were engaged in performing communicative tasks [4]. In other words, the researchers were interested in how corrective feedback fitted into communicative (or taskbased) language teaching, motivated by Long's (1991) proposal that for task-based language to be effective 'focus-on-form' is needed. According to Long this should occur while learners are struggling to communicate so that their attention is drawn to the linguistic forms that they need to express their own ideas and connections are made between the external processes involved in correcting errors and the internal processes involved in acquisition. This, however, raises an important question. Is corrective feedback more effective when it is delivered online in the context of learners' attempts to communicate - as Long maintains - or is it more (or equally) effective if teachers' wait until the communicative activity is completed and then correct the errors that they observed learners making?

This issue of special interest because teacher educators frequently advise teachers not to interrupt students during a communicative task and to delay correction until afterwards. Bohlke (2014), for example, commented that «during fluency activity, it is generally accepted that the teacher should not interrupt students to point out a grammar or vocabulary error, or to correct pronunciation» (pp. 127) and went on to claim that «many teachers feel that the only appropriate time to focus on error correction is after the activity is completed» (pp. 128). Ellis and Shintani (2014) argued that for research to be maximally relevant to teachers it should address issues of real pedagogical significance and not just issues derived from theory. Whether corrective feedback should be undertaken immediately or delayed is clearly an important pedagogical issue. However, there has, however, been little research to date - see Quinn and Nakata (1972) for a review of the limited research.Perhaps, as experimental research on corrective feedback continues, it should focus more on investigating the pedagogical advice that teachers receive [5].

\section{$4 \quad$ Meta-analysis of corrective feedback studies}

The enormous growth of experimental studies from the 1990s onwards resulted in a body of sufficiently well-designed studies to make meta-analysis possible. Meta-analysis involves the statistical analysis of previously published studies with a view to establishing the effect size of a particular treatment (in this case corrective feedback) and the impact that moderating variables have on this. There are now a number of published meta-analyses of corrective feedback studies(e.g. Russell and Spada, 2006; Mackey and Goo, 2007; Li, 2010; Lyster and Saito, 2010).

Li's (2010) meta-analysis is a good example of what meta-analysis can tell us about corrective feedback. Li meta-analysed a total of 33 oral corrective feedback studies involving 1,773 learners. He reported that «corrective feedback had a medium effect on acquisition» (p. 335), which was evident in tests immediately following the treatment involving corrective feedback and over time. He showed that the effect was much greater in studies carried out in a laboratory than in a classroom. Li also found that the effect of corrective feedback was greater in foreign language than in second language settings and suggested that this might be because learners in the former are more predisposed to pay attention to the corrections they received. Corrective feedback also proved more effective in treatments that involved discrete-item practice of grammatical structures (e.g. in drills), where the 
feedback is intensive and more likely to be noticed, than in communicative activities. Li also reported that the effects of $\mathrm{CF}$ were evident in both tests that measured controlled language use and free production suggesting that it affected implicit as well as explicit L2 knowledge.

\section{$5 \quad$ Back to descriptive research}

In outlining how research on corrective feedback has developed, I may have given the impression that descriptive research has given way to experimental research over time. In some ways this is what happened. Lyster and Ranta's (1997) study of corrective feedback in immersion classrooms led to a taxonomy of feedback types that was subsequently drawn in experimental studies (e.g. Lyster, 2004). But it would be a mistake to suggest that the role of descriptive research is simply to provide a basis for experimental research. Nor is this an accurate account of how corrective feedback research has evolved historically.

There is, in fact, a rich vein of descriptive research that has continued quite independently of experimental research.Conversational analysts have focused on 'repair', which they define as the treatment of 'trouble' (i.e. anything that the participants consider is impeding communication). In this respect, then 'repair' includes a wider range of phenomena than corrective feedback, which concerns the repair work undertaken to address trouble of a purely linguistic nature (i.e. learner errors).

One of the main contributions of the research on repair is to show how «the organization of repair varies with the pedagogical focus» (Seedhouse, 2004: 142). Seedhouse distinguished what he calls 'didactic repair' in form-and-accuracy contexts and 'conversational repair' in meaning-and-fluency contexts. Didactic repair arises when the teacher is trying to elicit a linguistically correct utterance from a student and the student fails to provide it. Typically, the teacher initiates the repair allowing the student the opportunity to self-repair. Seedhouse found that in meaning-and-fluency contexts conversational repair is much more likely to occur. Purely linguistic problems are often ignored and the teacher is often prepared to accept highly simplified learner language. Instead, repair-work occurs when there is a breakdown in communication, and, in particular when it is necessary to establish factual accuracy.

Conversational analysts view the research they undertake as much more than just descriptive they claim that it can illuminate how 'doing learning' takes place. In accordance with sociocultural theory they argue that participation in corrective feedback episodes is not just a source of learning but the actual site of learning. That is, learning occurs within the repair sequences that learners participate in. Some researchers (e.g. Markee, 2008) have used conversational analysis to investigate long-term learning by tracking how a specific linguistic object is addressed at different point of time. However, naturally-occurring classroom data do not readily afford instances of reoccurring 'learning objects' making it difficult to find evidence of long-term learning in this way. A limitation of research based on conversational analysisis is refusal to consider using tests to establish whether learning has taken place [6]. Nevertheless, conversational analytical studies have greatly enriched our understanding of how repair takes place through the detailed emic perspective it provides.

\section{$6 \quad$ Hendrickson's five key questions revisited}

It is informative to ask what all the research on corrective feedback has told us. In table 5 below I return to the five questions that Hendrickson (1978) posed and summarise what answers are now

available. Readers might like to compare the answers that Hendrickson gave (see table 1) with the answers I now give. 
Table 5: What we currently know about corrective feedback

\begin{tabular}{|c|c|}
\hline Question & Answers \\
\hline $\begin{array}{l}\text { Should learner errors be } \\
\text { corrected? }\end{array}$ & $\begin{array}{l}\text { It is now quite clear that correcting learner errors is beneficial for L2 acquisition. } \\
\text { Correction is beneficial in both communicative (fluency) and in accuracy }\end{array}$ \\
\hline
\end{tabular}

If so, when should learner The descriptive research shows that teachers frequently correct online (i.e. errors be corrected? while learners are performing an activity). The experimental research shows that this assists acquisition. However, currently little is known about the relative benefits of correcting immediately an error occurs or delaying correction until the activity is over.

Which learner errors should The descriptive research shows that teachers correct a wide range of different be corrected? types of errors. Experimental research has investigated focused corrective feedback (i.e. feedback directed at a pre-determined linguistic feature). Focused corrective feedback has been found to be effective. However, unfocused corrective feedback can also contribute to the elimination of errors. The research, however,provides no case for focusing just on 'global' errors; teachers regularly correct 'local' errors' and this has been shown to be effective and is arguably needed.

How should learner errors be This is the aspect of corrective feedback that has received the most attention corrected? from researchers. Descriptive research has led to typology of corrective feedback strategies based on the two dimensions (input-providing vs. outputprompting; implicit vs. explicit). Experimental research indicates that all types can help acquisition providing that the corrections are salient to learners. In this respect, explicit corrective strategies have been found to be generally effective. The research shows that it is not necessary for learners to repair their errors following correction but that such repair can be helpful.

Who should correct learner Researchers have mainly investigated teacher correction. Research shows that errors? learners do correct each other when working in small groups but not always consistently. The research lends the clearest support for teacher correction [7].

In some the proposals emanating from the research match the advice given to teachers in teacher guides (Ellis, 2017). For example, the guides recognize the need for correction. However, in other respects the research challenges the position taken in the guides. The guides generally recommend that teachers do not correct during fluency work but the research suggests that teachers in fact do this and also that it is effective in facilitating acquisition. The guides suggest restricting correction to global errors but this is not what teachers do and in any case there is a need to help learners eliminate their local errors and research indicates that corrective feedback helps with this. The guides recommend that teachers use a variety of corrective feedback strategies but emphasize the importance of pushing learners to repair their own errors. The research points to the efficacy of more explicit forms of correction and, while recognizing that learner repair can help, does not see repair as essential. Finally, the guides emphasize the importance of learner- as opposed to teacher-correction but the research 
lends the clearest support to teacher correction.

The teacher guides inevitably offer generalizations about how to do corrective feedback. But, what emerges very clearly from the research, is that corrective feedback is very complex and what is best in one context may not be in another. When oral corrective feedback is immediate it is an online phenomenon and thus subject to instant decision-making on the part of teachers. It is unlikely - and probably undesirable - that teachers will implement a strict correction policy. Inevitably, the corrections they provide will be inconsistent and messy - influenced, among other things, by individual differences in the students they are teaching. But teachers do need some guidelines and it seems sensible to ensure that these are informed by research.

\section{Conclusion}

The corrective feedback research that I have considered in this article has spanned fifty years. Initially, the research was descriptive in nature, providing much needed information about what teachers actually do when they correct students' errors. Later it was experimental, aimed first at establishing whether corrective feedback was effective in assisting acquisition, later at investigating what type of feedback was most effective, and, most recently, at examining how contextual and individual learner factors mediate its effect on acquisition. Experimental researchers have drawn on different theories of language learning leading them to investigate different ways in which corrective feedback fosters L2 development and resulting in different conclusions about what types of feedback are preferable. Other researchers have adopted conversation analysis as a way of exploring how learning takes place in situ when repair work takes place. This plethora of research is perhaps confusing to teachers but, as I have tried to show, I think it is possible to arrive at a number of research-based generalizations that can guide teachers.

Because of space limitations, my historical survey of the corrective feedback is by no means complete. I have had very little to say about how learners correct each other in small group work and nothing at all about feedback in computer-mediated communication. The latter has in fact become a major focus on enquiry and readers interested in it should look at Heift and Hegelheimer's (2017) review of the research.

\section{Notes}

${ }^{1}$ Not all researchers would agree that descriptive studies cannot show whether corrective feedback assists acquisition. Some researchers argue that descriptive studies can show learners 'doing learning'. ${ }^{2}$ This possibility is considered later in the article.

Some teachers use paralinguistic signals to indicate both than error has occurred and what type of error - for example, gesturing with one's thumb over one's shoulder indicates an error in the past tense.

${ }^{3}$ In fact, as several commentators have noted, recasts can be more or less implicit. Table 3 distinguishes conversational recasts which are implicit and didactic recasts which are explicit.

4 There have been other studies that have examined corrective feedback in accuracy-oriented instruction.

${ }^{5}$ The way Ellis and Shintani (2014) set out to investigate the pedagogical advice that teachers receive was by examining the propositions about corrective feedback found in popular teacher guides such as Ur (1996) and Scrivener (2005).

${ }^{6}$ Conversational analysts reject tests on the grounds that they do not show what learners can do in naturally occurring interactions. 
${ }^{7}$ Peer and self-correction, however, is clearly beneficial in the case of written errors. Peer correction is also potentially beneficial when learners are working on grammar exercises in pairs or small groups.

\section{References}

Aljaafreh, A.\& Lantolf, J. P. (1994). Negative feedback as regulation and second language learning in the Zone of Proximal Development. Modern Language Journal, 78(4), 465-483.

Allwright, R. L. (1975). Problems in the study of the language teacher's treatment of error. In M. K. Burt \& H. D. Dulay (Eds.), On TESOL '75: New directions in second language learning, teaching, and bilingual education (pp. 96-109). Washington, D.C.: TESOL.

Bohlke, D. (2014). Fluency-oriented second language teaching. In Celce-Murcia, M., D. Brinton \& M. Snow (Eds.). Teaching English as a second or foreign language Fourth Edition (pp. 121135). Boston, MA: Heinle Cengage

Burt, M. 1975. Error analysis in the adult EFL classroom. TESOL Quarterly 9, 53-63.

Chaudron, C. (1977). A descriptive model of discourse in the corrective treatment of learners' errors. Language Learning 27(1), 29-46.

Edmondson, W. (1985) Discourse worlds in the classroom and in foreign language learning. Studies in Second Language Acquisition 7, 159-68.

Ellis, R. (2017). Oral corrective feedback in L2 classrooms: What we know so far. In H. Nassaji \& E. Kartchava (Eds.). Corrective feedback in second language teaching and learning: Research, theory. applications, implications (pp. 3-18). Abingdon: Routledge.

Ellis, R., Loewen, S., \& Erlam, R. (2006). Implicit and explicit corrective feedback and the acquisition of L2 grammar. Studies in Second Language Acquisition 28, 339-368.

Ellis, R. \& Mifka-Provozic, N. (2013). Recasts, uptake and noticing. In J. Bergeleitner, S. Frota, \& J. Yoshioka (Eds). Noticing and Second Language Acquisition: Studies in Honor of Richard Schmidt (pp. 61-79). Honolulu: University of Hawaii, National Foreign Language Resource Center.

Erlam, R., R. Ellis, \& R. Batstone. (2013). Oral corrective feedback on L2 writing: Two approaches compared. System 41 (2), 257-268

Fanselow, J. (1977). The treatment of error in oral work. Foreign Language Annals 10, 583-593.

Heft, T \& Hegelheimer, V. (2017). Computer-assisted corrective feedback and language learning. In H. Nassaji \& E. Kartchava (Eds.). Corrective feedback in second language teaching and learning ( pp. 51-65). Abingdon: Routledge.

Hendrickson, J. M. (1978). Error correction in foreign language teaching: Recent theory, research, and practice. Modern Language Journal 62(8), 387-398.

Krashen, S. (1982). Principles and practice in second language acquisition. Oxford: Pergamon.

Krashen, S. (1985). The input hypothesis: Issues and implications. London ; New York: Longman.

Li, S. (2010). The effectiveness of corrective feedback in SLA: a meta-analysis. [Article]. Language Learning 60(2), 309-365..

Loewen, S. (2005). Incidental focus on form and second language learning. Studies in Second Language Acquisition 27(3), 361-386.

Long, M. 1991. Focus on form: a design feature in language teaching methodology. In K. de Bot, R. Ginsberg, \& C. Kramsch (Eds.). Foreign Language Research in Cross-cultural Perspective. Amsterdam: John Benjamins.

Long, M. B. (1977). Teacher feedback on learner error: mapping cognitions. In B. D. Brown, C. A. Yorio, and R. H. Crymes (eds.), Qn TESOL'77 Teachjng and learning English as a second 
language; Trends in research and practice (pp. 278-293.Washington, D. C.: TESOL.

Long, M. (1996). The role of the linguistic environment in second language acquisition. In W. Ritchie and T. Bhatia (Eds.). Handbook of Second Language Acquisition. San Diego: Academic Press.

Long, M. H. (2006). Problems in SLA. Mahwah, N.J.: Lawrence Erlbaum Associates.

Lyster, R, Recasts, repetition and ambiguity in L2 classroom discourse. Studies in Second Language Acquisition 20 (1), 51-81

Lyster, R. (2004). Differential effects of prompts and recasts in form-focused instruction. Studies in Second Language Acquisition 26(3), 399-432.

Lyster, R., \& Ranta, L. (1997). Corrective feedback and learner uptake. Studies in Second Language Acquisition 19(1), 37-66.

Lyster, R., \& Saito, K. (2010). Oral feedback in classroom SLA. Studies in Second Language Acquisition 32(Special Issue 2), 265-302.

Mackey, A. (2006). Feedback, noticing and instructed second language learning. Applied Linguistics 27(3), 405-430.

Mackey, A., \& Goo, J. M. (2007). Interaction research in SLA: A meta-analysis and research synthesis. In A. Mackey (Ed.), Input, interaction and corrective feedback in L2 learning (pp. 379-452). Oxford: Oxford University Press.

Markee, N. (2008). Toward a learning behavior tracking methodology for CA-for-SLA. Applied Linguistics 29, 404-427.

Mifka Profozic, N. (2013). The effectiveness of corrective feedback and the role of individual differences in language learning: A Classroom Study. Frankfurt-am-Main: Peter Lang.

Nassaji, H., \& Swain, M. (2000). A Vygotskian perspective on corrective feedback in L2: The effect of random versus negotiated help on the learning of English articles. Language Awareness 9(1), 34-51.

Nystrom, N. (1983). Teacher-student interaction in bilingual classrooms: four approaches to error feedback. In H. W. Seliger \& M. H. Long (Eds.), Classroom oriented research in second language acquisition (pp. 169-188). Rowley, MA: Newbury House.

Quinn, P., \& Nakata, T. (2017). The timing of oral corrective feedback. In H. Nassaji \& E. Kartchava (Eds.), Corrective feedback in second language teaching and learning: Research, theory, applications, implications (pp. 35-47). Abingdon, UK: Routledge.

Révész, A. (2012). Working memory and the observed effectiveness of recasts on different L2 outcome measures. Language Learning 62, 93-132.

Russell, J., \& Spada, N. (2006). The effectiveness of corrective feedback for the acquisition of L2 grammar. In J. M. Norris \& L. Ortega (Eds.), Synthesizing research on language learning and teaching (pp. 133-164). Amsterdam: John Benjamins.

Schmidt, R. (1990). The role of consciousness in second language learning. Applied Linguistics, 11(2), 129-158

Scrivener, J. (2005). Learning teaching: A guidebook for English language teachers. Oxford: MacMillan Education.

Seedhouse, P. (2004). The interactional architecture of the language classroom: A conversation analysis perspective. Malden, MA: Blackwell.

Sheen, Y. (2004). Corrective feedback and learner uptake in communicative classrooms across instructional settings. Language Teaching Research 8, 263-300.

Sheen, Y. (2008). Recasts, language Anxiety, modified output, and L2 .earning. Language Learning $58,835-874$. 
Sheen, Y. and Ellis, R. (2011). Corrective feedback in language teaching. In E. Hinkel (Ed.). Handbook of research in second language teaching and learning (2 ${ }^{\text {nd }}$ edition) (pp. 593-610). New York: Routledge.

Spada, N, \& Lightbown, P. M. (1993). Instruction and the development of questions in L2 classrooms. Studies in Second Language Acquisition 15, 205-224.

Ur, P. (1996). A course in language teaching: Practice and theory Cambridge: Cambridge University Press. 